\title{
Structure of $\boldsymbol{N}$-(3,4-Dimethoxyphenyl)pyrido $\left[3^{\prime}, 2^{\prime}: 4,5\right]$-thieno $[3,2-d]$ pyrimidin-4-amine, a New Inhibitor of CLK1 and DYRK1A Kinases
}

\author{
Jean Guillon, ${ }^{1}$ Mathieu Marchivie, ${ }^{1}$ Yvonnick Loidreau, ${ }^{2}$ \\ Noël Pinaud, ${ }^{3}$ and Thierry Besson ${ }^{2}$ \\ ${ }^{1}$ Université Bordeaux Segalen, CNRS FRE 3396 - Pharmacochimie, F-33076 Bordeaux, France \\ ${ }^{2}$ Université de Normandie, COBRA, UMR 6014 \& FR 3038 and Université de Rouen, INSA Rouen, CNRS, IRCOF, \\ 76821 Mont-Saint-Aignan Cedex, France \\ ${ }^{3}$ ISM-CNRS UMR 5255, Université de Bordeaux, 33405 Talence Cedex, France
}

Correspondence should be addressed to Jean Guillon; jean.guillon@u-bordeaux2.fr

Received 9 September 2013; Accepted 21 November 2013

Academic Editors: M. Akkurt, L. R. Gomes, A. R. Ibrahim, and J. Jasinski

Copyright (C) 2013 Jean Guillon et al. This is an open access article distributed under the Creative Commons Attribution License, which permits unrestricted use, distribution, and reproduction in any medium, provided the original work is properly cited.

The complete crystal structure of $N$-(3,4-dimethoxyphenyl)pyrido $\left[3^{\prime}, 2^{\prime}: 4,5\right]$ thieno[3,2-d]pyrimidin-4-amine, synthesized via a Dimroth rearrangement and designed as new inhibitor of CLK1 and DYRK1A kinases, was established by a single-crystal X-ray diffraction. The crystal is orthorhombic, space group $P \mathrm{ca}{ }_{1} ; a=13.1593$ (9), $b=13.9823$ (10), $c=8.5403$ (7) $\AA, \alpha=\beta=\gamma=90^{\circ}$, $V=1571.4(2) \AA^{3}$, and $Z=4, \mathrm{C}_{17} \mathrm{H}_{14} \mathrm{~N}_{4} \mathrm{O}_{2} \mathrm{~S}$. Solid-state data could be used to enlighten the biological mechanism of action.

\section{Introduction}

Kinases are one of the largest families of the genome. More than 500 kinases play an important role in the regulation of various cellular processes. These enzymes are involved in all major diseases, including cancer, neurodegenerative disorders, and cardiovascular diseases.

Among them, the Ser/Thr kinases CDK5, GSK3, DYRK1A, CLK1, and CK1 constitute a family showing a strong implication in various regulation processes, especially Alzheimer's disease [1-3]. Following our search for such Ser/Thr kinases inhibitors of potential therapeutic interest, we previously identified a series of novel $N$-arylbenzo[ $[b]$ thieno[3,2d]pyrimidin-4-amines, synthesized via a Dimroth rearrangement $[4,5]$.

We report herein the crystal structure of $N$ - $(3,4-$ dimethoxyphenyl)pyrido $\left[3^{\prime}, 2^{\prime}: 4,5\right]$ thieno[3,2-d]pyrimidin4-amine (Figure 1), which shows interesting selectivity towards CLK1 and DYRK1A kinases $\left(\mathrm{IC}_{50}=3.4\right.$ and $2.9 \mu \mathrm{M}$, resp.) over the other tested kinases $[4,5]$.
The present crystal structure determination will not only help us to understand the detailed three-dimensional arrangement of the compound, which could be useful for designing new derivatives, but also contribute to the structural database in which there are very few structures containing the benzo $[b]$ thieno[3,2-d]pyrimidine skeleton $[6,7]$. Moreover, solid-state data could be used to clarify the mechanism of action implicating this new CLK1 and DYRK1A kinases inhibitor.

\section{Experimental}

$N$-(3,4-Dimethoxyphenyl)pyrido $\left[3^{\prime}, 2^{\prime}: 4,5\right]$ thieno[3,2-d]pyrimidin-4-amine was synthesized as previously described by Loidreau et al. [4]. Colourless crystals of title compound suitable for X-ray analysis were obtained by slow evaporation from a dichloromethane-methanol solution $4: 1(\mathrm{v} / \mathrm{v})$ at room temperature. 


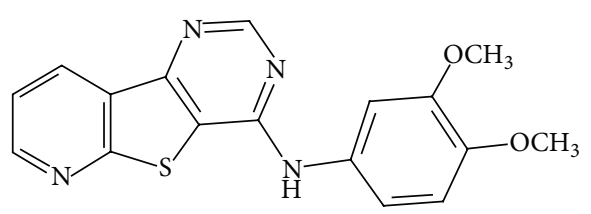

FIGURE 1: Structure of $N$-(3,4-dimethoxyphenyl)pyrido $\left[3^{\prime}, 2^{\prime}: 4,5\right]$ thieno[3,2- $d]$ pyrimidin-4-amine.

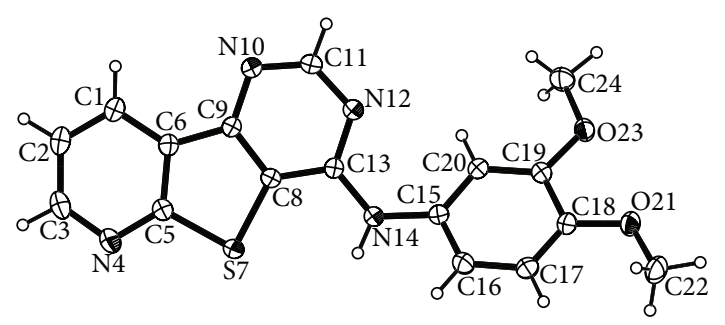

FIGURE 2: ORTEP diagram of $N$-(3,4-dimethoxyphenyl)pyrido[ $3^{\prime}$, $\left.2^{\prime}: 4,5\right]$ thieno[3,2- $\left.d\right]$ pyrimidin-4-amine. Displacement ellipsoids are drawn at the $30 \%$ probability level.

\section{Refinement}

A single crystal of the title compound with dimensions $0.10 \times$ $0.10 \times 0.01 \mathrm{~mm}$ was chosen for X-ray diffraction study. The data were collected on a Rigaku $R$-axis rapid diffractometer equipped with microfocus rotating anode using the monochromatic $\mathrm{Cu}-\mathrm{K} \alpha$ radiation $(\lambda=1.5418 \AA)$ and a curved image plate detector at $293(2) \mathrm{K}$. In the range of $6.73^{\circ}<\theta<72.00^{\circ}$, a total of 21,370 reflections were collected, of which 2936 were independent $\left(R_{\text {int }}=0.0789\right)$ and 2837 were observed with $I>2 \sigma(I)$. The structure was solved by direct methods with SHELXS97 $[8,9]$. Nonhydrogen atoms were refined by full-matrix least-squares techniques on $F^{2}$ with anisotropic thermal parameters, using SHELXL97 $[8,9]$. H atoms were treated according to the riding model during refinement with fixed bond length, of $0.93 \AA, 0.96 \AA$, and $0.86 \AA$ for $\mathrm{C}_{\text {arom }}{ }^{-}$ $\mathrm{H}, \mathrm{C}_{\text {methyl }}-\mathrm{H}$, and $\mathrm{N}-\mathrm{H}$ bonds, respectively. The isotropic displacement parameters have been fixed at 1.2 times the $U_{\text {eq }}$ of the $s p^{2}$ atom or 1.5 times the $U_{\text {eq }}$ of the $s p^{3}$ atom from which the $\mathrm{H}$ atoms are linked to. All the drawings were performed using the graphical interface found within the OLEX2 package [10]. The crystal data and refinement details are listed in Table 1. Table 2 lists the bond geometries and Table 3 lists the hydrogen bonds.

\section{Results and Discussion}

The molecular structure of $N$-(3,4-Dimethoxyphenyl)pyrido $\left[3^{\prime}, 2^{\prime}: 4,5\right]$ thieno[3,2-d]pyrimidin-4-amine is depicted in Figure 2 . The title compound crystallized in the orthorhombic system, space group $P$ ca 2 with unit cell parameters: $a=$ 13.1593 (9), $b=13.9823$ (10), $c=8.5403$ (7) $\AA, \alpha=\beta=\gamma=90^{\circ}$, $V=1571.4(2) \AA^{3}, \mathrm{Z}=4, \mathrm{C}_{17} \mathrm{H}_{14} \mathrm{~N}_{4} \mathrm{O}_{2} \mathrm{~S}, \mathrm{D}_{c}=1.430 \mathrm{~g} / \mathrm{cm}^{3}, \lambda$ $(\mathrm{CuK} \alpha)=1.5418 \AA, S=1.016, F(000)=704$, and $T=293(2) \mathrm{K}$.
TABLE 1: Crystallographic data and structure refinement details.

\begin{tabular}{|c|c|}
\hline Chemical formula & $\mathrm{C}_{17} \mathrm{H}_{14} \mathrm{~N}_{4} \mathrm{O}_{2} \mathrm{~S}$ \\
\hline Formula weight & 338.38 \\
\hline Temperature (K) & $293(2)$ \\
\hline Wavelength $(\AA)$ & 1.54180 \\
\hline Crystal size (mm) & $0.10 \times 0.10 \times 0.01$ \\
\hline Crystal system & Orthorhombic \\
\hline Space group & $P \mathrm{ca} 2_{1}$ \\
\hline$a(\AA)$ & $13.1593(9)$ \\
\hline$b(\AA)$ & $13.9823(10)$ \\
\hline$c(\AA)$ & $8.5403(7)$ \\
\hline$\alpha\left(^{\circ}\right)$ & 90 \\
\hline$\beta\left(^{\circ}\right)$ & 90 \\
\hline$\gamma\left({ }^{\circ}\right)$ & 90 \\
\hline$V\left(\AA^{3}\right)$ & $1571.4(2)$ \\
\hline $\mathrm{Z}$ & 4 \\
\hline $\mathrm{D}_{c}\left(\mathrm{~g} / \mathrm{cm}^{3}\right)$ & 1.430 \\
\hline$F(000)$ & 704 \\
\hline Absorption coeff. $\left(\mathrm{mm}^{-1}\right)$ & 1.987 \\
\hline$\theta$ range $\left(^{\circ}\right)$ & $6.73-72.00$ \\
\hline Index ranges & $\begin{array}{c}-16 \leq h \leq 16 ;-17 \leq k \leq 16 \\
-10 \leq l \leq 8\end{array}$ \\
\hline Reflection collected & 21,370 \\
\hline Independent reflections & $2936\left[R_{\mathrm{int}}=0.0789\right]$ \\
\hline Observed reflections & 2837 \\
\hline Data/restraints/parameters & $2936 / 1 / 219$ \\
\hline Goodness-of-fit on $F^{2}$ & 1.016 \\
\hline$R, w R$ indices $[I>2 \sigma(I)]$ & $0.0420,0.0960$ \\
\hline$R, w R$ indices (all data) & $0.0428,0.0972$ \\
\hline $\begin{array}{l}\text { Largest diff. peak and hole } \\
\left(\mathrm{e} \AA^{-3}\right)\end{array}$ & $0.536,-0.249$ \\
\hline Flack parameter [11] & $-0.001(18)$ \\
\hline
\end{tabular}

The key bond lengths and bond angles of the title compound are very similar to those given in the literature for substituted phenylbenzo[3,2-d]pyrimidinones [6,7].

The pyrido $\left[3^{\prime}, 2^{\prime}: 4,5\right]$ thieno $[3,2-d]$ pyrimidine system of this new CLK1 and DYRK1A kinases inhibitor is nearly planar with a mean out-of-plane deviation of $0.025 \AA$ with the largest deviation of 0.0424 (18) $\AA$ for atom N12.

The C8-S7 and C5-S7 bond lengths in the thiophene moiety of the pyrido-thieno-pyrimidine compound are noticed at 1.7406 (18) and 1.755 (2) $\AA$, respectively (Table 2), which is comparable to the $\mathrm{Cs} p^{2}-\mathrm{S}$ expected distances [12].

The values of the four $\mathrm{C}-\mathrm{N}$ bonds $(\mathrm{C} 13-\mathrm{N} 12=1.338$ (2) $\AA$, $\mathrm{C} 11-\mathrm{N} 12=1.338$ (3) $\AA, \mathrm{C} 11-\mathrm{N} 10=1.321$ (3) $\AA$, and C9-N10 = $1.354(2) \AA)$ in the pyrimidine skeleton were also in agreement with the $\mathrm{C}\left(s p^{2}\right)-\mathrm{N}$ expected distance [12].

The amidine bond angle N12-C13-N14, at the junction of the pyrimidine and aniline rings observed at $120.45(17)^{\circ}$, the relatively short N12-C13 and C13-N14 bond lengths measured at 1.338 (2) and 1.349 (2) $\AA$, respectively, and the planar 
TABLE 2: Selected bond lengths $(\AA)$ and angles $\left({ }^{\circ}\right)$.

\begin{tabular}{lccc}
\hline Bond lengths & & & \\
C8-S7 & $1.7406(18)$ & C11-N12 & $1.338(3)$ \\
C5-S7 & $1.755(2)$ & C11-N10 & $1.321(3)$ \\
C13-N12 & $1.338(2)$ & C9-N10 & $1.354(2)$ \\
Angles and torsion angles & & & $171.91(19)$ \\
N12-C13-N14 & $120.45(17)$ & C19-C18-O21-C22 & $176.8(2)$ \\
C17-C18-O21-C22 & $-7.3(3)$ & C18-C19-O23-C24 & \\
C20-C19-O23-C24 & $-3.1(3)$ & & \\
\hline
\end{tabular}

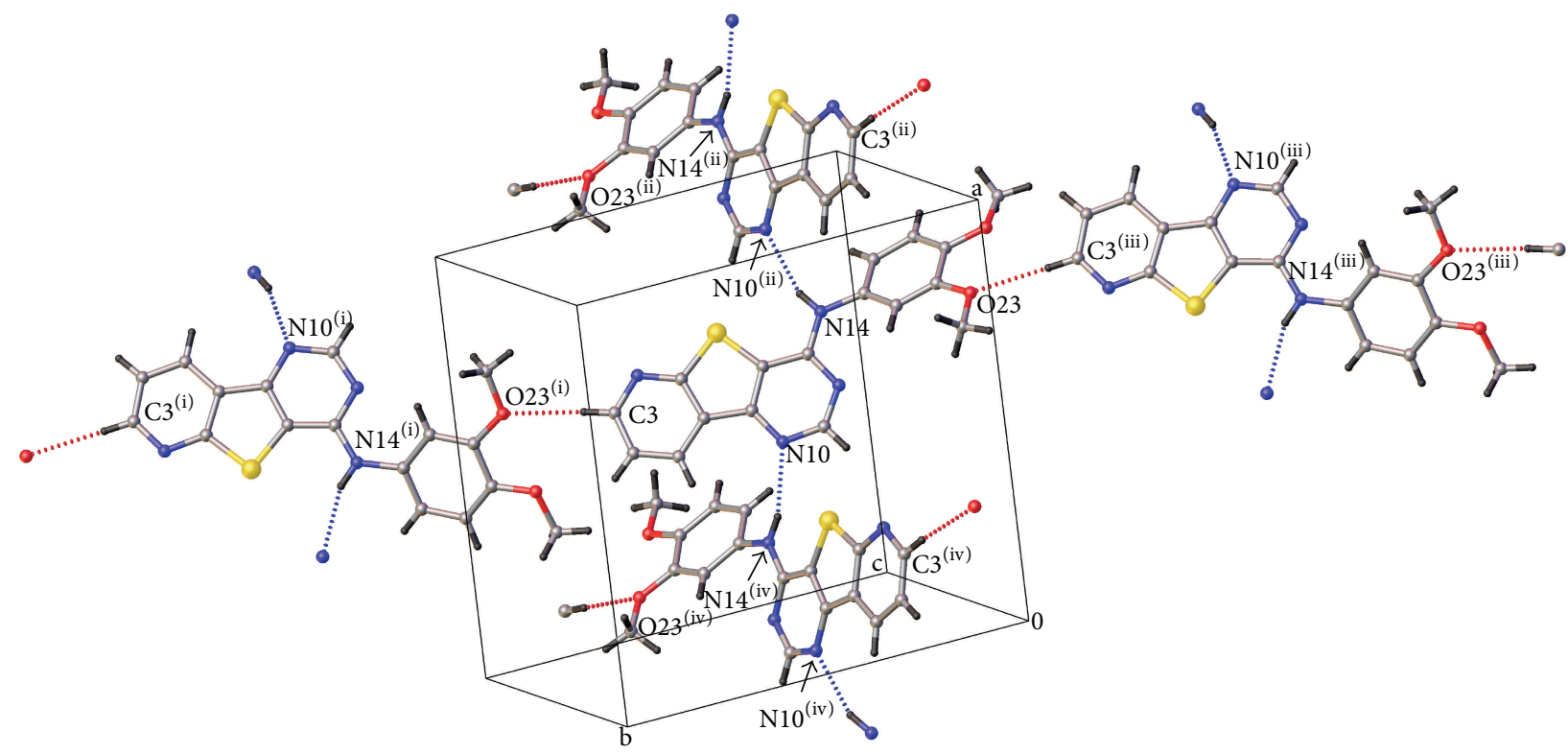

Figure 3: Partial molecular packing of $N$-(3,4-dimethoxyphenyl)pyrido $\left[3^{\prime}, 2^{\prime}: 4,5\right]$ thieno[3,2- $\left.d\right]$ pyrimidin-4-amine showing the selected $H$ bond type intermolecular contacts in the crystal lattice. Symmetry codes: (i) $-x+3 / 2, y+1, z+1 / 2$; (ii) $x+1 / 2,-y+1, z$; (iii) $-x+3 / 2$, $y-1, z-1 / 2$; (iv) $x-1 / 2,-y+1, z$.

TABLE 3: Hydrogen-bonding geometry $\left(\AA,^{\circ}\right)$.

\begin{tabular}{lcccc}
\hline $\mathrm{D}-\mathrm{H} \cdots \mathrm{A}$ & $\mathrm{D}-\mathrm{H}$ & $\mathrm{H} \cdots \mathrm{A}$ & $\mathrm{D} \cdots \mathrm{A}$ & $\mathrm{D}-\mathrm{H} \cdots \mathrm{A}$ \\
\hline $\mathrm{C} 3-\mathrm{H} 3 \cdots \mathrm{O} 23^{\mathrm{i}}$ & 0.93 & 2.48 & $3.406(3)$ & 175 \\
$\mathrm{~N} 14-\mathrm{H} 14 \cdots \mathrm{N} 10^{\mathrm{ii}}$ & 0.86 & 2.26 & $3.075(2)$ & 159
\end{tabular}

Symmetry codes: ${ }^{\mathrm{i}}-x+3 / 2, y+1, z+1 / 2 ;{ }^{\text {ii }} x+1 / 2,-y+1, z$.

geometry of the $\mathrm{C} 8-\mathrm{C} 13-\mathrm{N} 14-\mathrm{H} 14$ fragment (torsion angle $=$ $\left.-3.5(3)^{\circ}\right)$ are in good agreement with $s p^{2}$ hybridization of the $\mathrm{C}$ and $\mathrm{N}$ atoms with an electronic delocalization on the whole $N$-arylbenzo[b]thieno[3,2- $d]$ pyrimidin-4-amine skeleton. On the other hand, the significantly longer C15N14 bond length (1.420 (2) $\AA$ ) and the nonplanar geometry of the C16-C15-N14-H14 fragment (torsion angle $=31.1(3)^{\circ}$ ) indicate that the electronic delocalization stops on N14 and is not conjugated with the phenyl group. This feature may be due to the significant tilt angle between the least-squares planes defined by the pyridothienopyrimidine moiety and the aniline system that was approximately measured at $36.4(1)^{\circ}$.
The six $\mathrm{C}-\mathrm{C}$ bonds in the phenyl ring lie in the range 1.373 (3)-1.411 (3) A as expected for a fully $\pi$ delocalized benzyl system. Furthermore, the two methoxy groups were also found in plane of the phenyl system. Hence, the torsion angles $\mathrm{C}_{\text {arom }}-\mathrm{C}_{\text {arom }}-\mathrm{O}-\mathrm{C}_{\text {methyl }}$ bearing the methoxy group deviate from planarity by a maximum of $8.1(2)^{\circ}$ (Table 2 ). Such planarity denotes a partial delocalization of the $\pi$ electronic system onto the methoxy groups. The relatively high values of the two $\mathrm{C}_{\text {arom }}-\mathrm{O}-\mathrm{CH}_{3}$ angles $\left(\mathrm{C} 19-\mathrm{O} 23-\mathrm{C} 24=117.4(2)^{\circ}\right.$ and $\left.\mathrm{C} 18-\mathrm{O} 21-\mathrm{C} 22=116.7(2)^{\circ}\right)$ confirm this behaviour, as the oxygen atom geometry is consistent with the $s p^{2}$ hybridization. This type of geometry is observed for $60 \%$ of phenylmethoxy systems within the CSD database [13].

The crystal structure cohesion is essentially ensured by a three-dimensional network of hydrogen bonding interactions as shown by Figure 3. Note that from all the represented hydrogen interactions in Figure 3, only two of them are symmetrically independent and correspond to those listed in Table 3. 


\section{Extra Crystallographic Data}

Supplementary crystallographic data for $N$-(3,4-dimethoxyphenyl)pyrido $\left[3^{\prime}, 2^{\prime}: 4,5\right]$ thieno $[3,2-d]$ pyrimidin-4-amine, CCDC 925040, can be obtained free of charge via http:// www.ccdc.cam.ac.uk/ or from the Cambridge Crystallographic Data Centre, University Chemical Lab, Lensfield Road, Cambridge, UK.

\section{Acknowledgments}

Financial support from the Région Haute-Normandie (France) is gratefully acknowledged for the doctoral fellowships to Yvonnick Loidreau. The authors thank the LABEX SynOrg (ANR-11-LABX-0029) and AI-Chem Channel program for financial support.

\section{References}

[1] M. Flajolet, G. He, M. Heiman, A. Lin, A. C. Nairn, and P. Greengard, "Regulation of Alzheimer's disease amyloid- $\beta$ formation by casein kinase I," Proceedings of the National Academy of Sciences of the United States of America, vol. 104, no. 10, pp. 4159-4164, 2007.

[2] H. Weinmann and R. Metternich, "Drug discovery process for kinase inhibitors," ChemBioChem, vol. 6, no. 3, pp. 455-459, 2005.

[3] P. Cohen, "Protein kinases-the major drug targets of the twenty-first century?" Nature Reviews Drug Discovery, vol. 1, no. 4, pp. 309-315, 2002.

[4] Y. Loidreau, P. Marchand, C. Dubouilh-Benard et al., "Synthesis and biological evaluation of $N$-arylbenzo[b]thieno[3,2d]pyrimidin-4-amines and their pyrido and pyrazino analogues as Ser/Thr kinase inhibitors," European Journal of Medicinal Chemistry, vol. 58, pp. 171-183, 2012.

[5] Y. Loidreau, P. Marchand, C. Dubouilh-Benard, M. R. Nourrisson, M. Duflos, and T. Besson, "First synthesis of 4-aminopyrido[ $\left[2^{\prime}, 3^{\prime}: 4,5\right]$ furo[3,2-d] pyrimidines," Tetrahedron Letters, vol. 53, no. 8, pp. 944-947, 2012.

[6] S. Z. Xu, Y. G. Hu, X. Wang, and M. W. Ding, "2-ethoxy-3phenyl-1-benzothieno[3,2-d]pyrimidin-4(3H)-one," Acta Crystallographica Section E, vol. 62, no. 6, pp. o2229-o2230, 2006.

[7] S. Z. Xu, H. Luo, and A. H. Zheng, "2-diethylamino-3-(4methylphenyl)-1-benzothieno[3,2-d]pyrimidin-4(3H)-one," Acta Crystallographica Section E, vol. 62, no. 12, pp. o582805829, 2006.

[8] G. M. Sheldrick, SHELX97. Programs for Crystal Structure Analysis, University of Göttingen, Göttingen, Germany, 1997.

[9] G. M. Sheldrick, "A short history of SHELX," Acta Crystallographica Section A, vol. 64, no. 1, pp. 112-122, 2007.

[10] O. V. Dolomanov, L. J. Bourhis, R. J. Gildea, J. A. K. Howard, and H. Puschmann, "OLEX2: a complete structure solution, refinement and analysis program," Journal of Applied Crystallography, vol. 42, no. 2, pp. 339-341, 2009.

[11] H. D. Flack, "On enantiomorph-polarity estimation," Acta Crystallographica A, vol. 39, no. 6, pp. 876-881, 1983.

[12] F. H. Allen, O. Kennard, D. G. Watson, L. Brammer, A. G. Orpen, and R. Taylor, "Tables of bond lengths determined by $\mathrm{x}$-ray and neutron diffraction. Part 1: bond lengths in organic compounds," Journal of the Chemical Society, Perkin Transactions 2, no. 12, pp. S1-S19, 1987.
[13] I. J. Bruno, J. C. Cole, P. R. Edgington et al., "New software for searching the Cambridge Structural Database and visualizing crystal structures," Acta Crystallographica Section B, vol. 58, no. 3, pp. 389-397, 2002. 

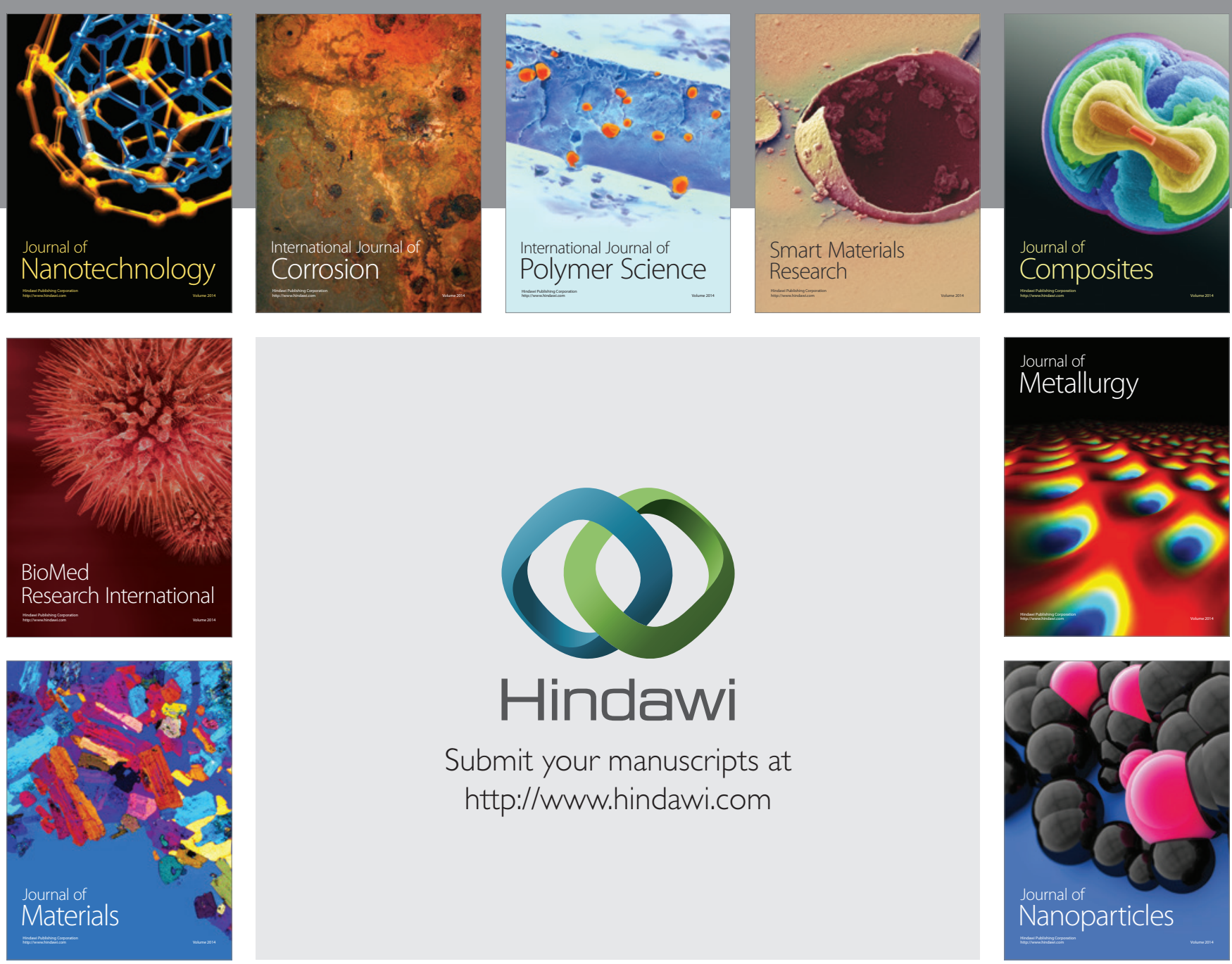

Submit your manuscripts at http://www.hindawi.com
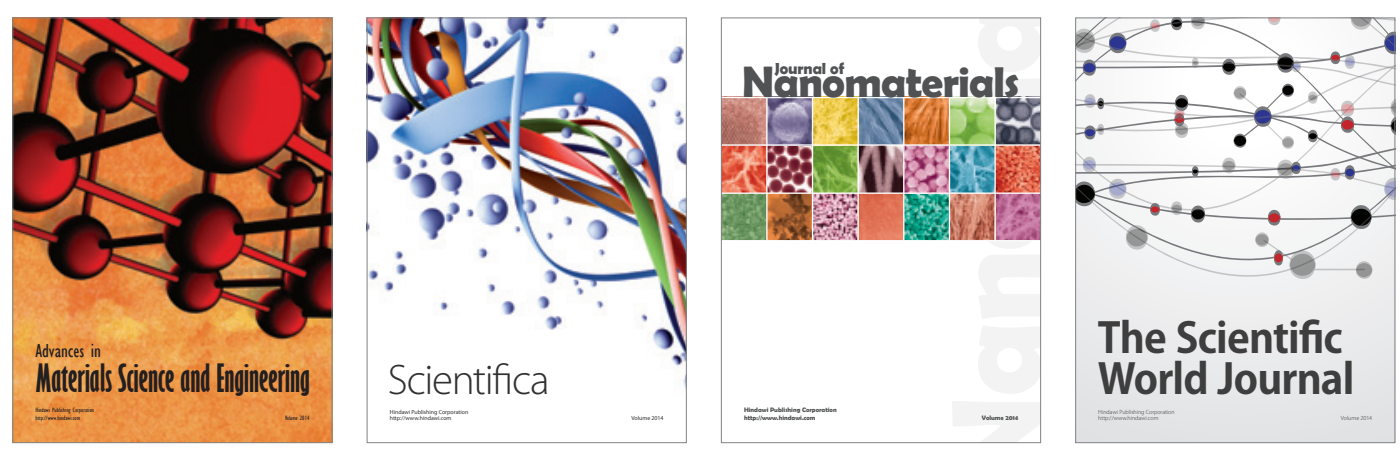

\section{The Scientific World Journal}
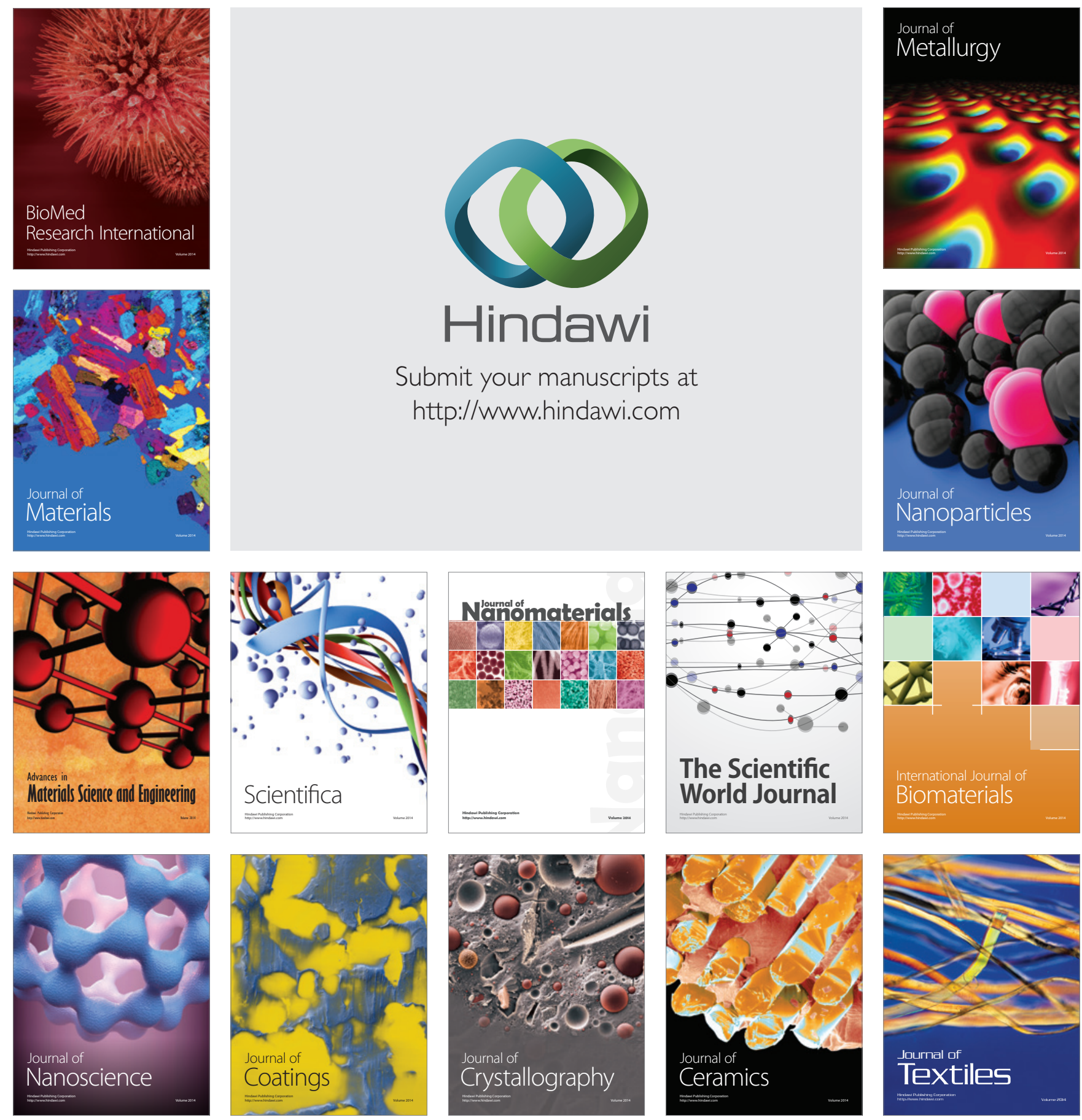